\title{
The Scourge of Financial Frauds in Foreign Investments: The Prespective of Nigeria- U. S. Bilateral Trade, 1990-2003
}

\author{
Bose O. Okuntola, (Ph.D) \\ Department of History and International Studies, Lagos State University, Ojo
}

\begin{abstract}
Attracting foreign private capital investment intricately revolves round the attractiveness and condusiveness of the domestic environment of the recipient. From the 1980s, the Nigerian economy was characterised by rapid industrial declines, depicted foreign exchange earnings, political instability and policy inconsistency and collapse in infrastructural facilities as well as the scourge of commercial and financial frauds; all which made the commercial environment not conducive not only for foreign investors, but also for the local ones. Consequently, government adopted economic diplomacy in 1988 as one of the modalities for attracting foreign investors and for managing the huge external debt crisis. This was backed up a fundamental review of Nigeria's industrial policy was made in 1989 and 1995, which provided greater incentives for foreign investors' participation. Despite these, the question of unfavourable commercial environment, particularly the scourge of financial and commercial frauds remained one of the major challenges. While American private sector made significant investment in other African countries like Egypt and South Africa, but deliberately ignored the Nigerian markets because of the problem of frauds; among other considerations. This paper examines the challenges of financial and commercial frauds on American private capital in the Nigerian economy between 1990 and 2003
\end{abstract}

\section{Introduction}

The sharp practices of commercial fraud have always been a feature of international trade and they are often precipitated and accentuated during economic depression. The World economic depression on West African coast in which prices of agricultural export produce collapsed in the international markets witnessed a wide spread of trade malpractices in major commercial cities. The 1980s World economic depression, which was precipitated by the collapse in the prices of crude oil in the international markets, marked another era of large scale commercial fraud in international trade. They were accentuated by the breakdown of business ethical relationships in international trade and investment, which in turn was buoyed up by the revolution in information technology and computer science. The use of the internet brought the world together in a global village, which some dubious businessmen exploited to frustrate international trade and investment opportunities. The phenomenon was known as "Transnational Organised Crime', otherwise referred to as the Advance Fee Fraud.

Advance Fee Fraud was and is still an organised syndicate across national borders, which involve unscrupulous manipulation of money exchange for investments or imports. It is a phrase used to describe a variety of offences, which involved fraudulent activities relating to the financing of huge projects investments or currency transactions under false pretence. In Nigeria, the offence is punishable under Section 419 of the Nigerian Penal Code, hence the Nigerian pseudonym "419". The most common advance fee fraud scheme from Nigeria consisted of deluge of letters sent through the mail and/or by fax, proposing fictitious 'business opportunities' most of which were intended to appeal to the recipient's greed. Since Government adopted the International Monetary Funds/World Bank Structural Adjustment Programme in 1986, the decline in industrial development and the need to inject foreign private capital in economic became one of the object of the programme. In 1989 and 1995, the new policy focused on attracting foreign investors, but the response was not encouraging. Their grouse centre principally on the high prevalence of crimes; commercial fraudulent practices and drug trafficking as well as policy inconsistency and political instability, which in the opinion of the international community was summed up "image problem". Walter Carrington, the U. S. Ambassador to Nigeria summed up the impact of image problem in his address during one of the monthly Luncheon meetings of the Nigerian-American Chamber of Commerce in 1996 thus:

The principal reason U. S. is shying away from Nigeria,...compared to other markets, is the famous image problem...there is crime problem in Nigeria...There are thousands of U. S. business and citizens whose only knowledge of Nigeria is the 419 scam letter they received .News such as the recent drug bust in Chicago of a ring allegedly led by Nigerian women, only reinforces this image of criminality. 
It is against this background that this present paper focuses on challenge of financial and commercial frauds in foreign investment from the perspective of Nigeria-U.S. bilateral trade between 1990 and 2000.

\section{The Background to Fraud Scourge: World Economic Depression and Nigeria's Economic Crisis}

Since 1970, Nigeria's foreign exchange earning depended largely on her sales of crude oil, while agricultural exports reduced significantly. Her first substantial benefits from oil exports occurred when the Organisation of Petroleum Exporting Countries (OPEC), to which Nigeria became a member in 1971 instigated the first oil crisis by boycotting oil exports to the Western countries accused of complicity during the IsrealiArab war of 1973. Between 1973 and 1974, oil price in the international markets quadrupled, which created major international crisis, but a stroke of fortune to the Nigeria's foreign exchange earnings. Her oil production increased from about 0.8 million barrels a day in the mid 1970 to 2.3 million barrels a day in December 1973, which made her the world's sixth largest oil producer. Her earnings from oil exports shot up from $\$ 1$ million in 1971 to about $\$ 8$ billion in 1974. By 1978, a barrel of crude oil sold for US\$14.9, increased to US\$33 b/d in 1979 and to US\$44.4 b/d in 1980 and Nigeria accumulated N65 billion of revenue. Imports became liberalised, tariffs were reduced and expenditure on capital goods rose from N 8.25 billion in 1975 to N13.291 billion in 1979 and further to N23.695 billion in 1980. Also, importation of consumer goods increased substantially from N440 million in 1974 to N2.136 billion in 1978 and to N3.897 billion in 1981. Raw materials importation increased from N519.3 million in 1974 to N1.880 billion in 1978 and to N3.038 billion in 1981 Investment expenditure estimated at about N70 billion in current prices over the period 1973 to 1981 surpassed the value of revenue received.

By the beginning of 1980 , efforts made by the consuming countries at reducing consumption of the commodity and provide solution on sharing agreement had started to yield fruits. As Britain and Norway explored new oil fields in the North Sea and Mexico, Nigeria's oil exports faced stiff competition. By the mid1980, Nigeria's economy stagnated by a mere 0.5 per cent as a result of glut in the oil markets. Between 1982 and 1983, the country's total income fell from N28.5 billion to 27.3 billion, a drop of 4.4 per cent. Inter-sectoral financing activities in Nigeria reflected the unsatisfactory economic performance. The volume of net intersectoral financing fell from its high level of N12, 176.4 million in 1980 to as low as N4, 381 million in 1981. Most of the transactions were recorded in the Foreign Exchange markets (N3, 068.5 million), Domestic loans and Advances (N3, 003.8 million) and Government Loan and Shares (N2, 630.2 million). Other markets included; markets for Federal Debts (N877.5 million), Currency and Deposits (N441.7 million) and Other Debt (N382 million).

However, by April of the same year, the seriousness of the crisis became more obvious. At the domestic front, importation of goods was drastically reduced and by 1983, import restrictions reduced trade from Western Europe by 75 per cent to the extent that some independent shipping lines considered pulling out of the West African business. American exporters also dropped by about 55 per cent, which was higher than that of the Western Germany and French exports. British exports into the Nigerian markets also dropped from 30 per cent in 1982 to 50 per cent in 1983. This was expressed by the London Chamber of Commerce and Industry:

The British exporters especially have a great deal to lose if there is a permanent change in the pattern of Nigerian imports, and although some firms clearly reacted with panic. The general line was one of keeping cool and treating the crisis as the temporary one.

With falling economic fortune some unscrupulous importers resulted into all shades of commercial fraud into which many foreign investors and traders fell victims despite government policy on attracting foreign investors. Indeed, government admitted this much in the budget speech of 1992. In comparative terms the total investment of the U.S.A in Nigeria, which stood \$ $161 \mathrm{~m}$ in 1990 and increased to $\$ 611 \mathrm{~m}$ in 1991 slumped to $\$ 274 \mathrm{~m}$ in 1992 . In the same period, Egypt attracted U. S. investment to the tune of $\$ 1,465 \mathrm{~m}$ in $1990, \$ 1,239 \mathrm{~m}$ and $\$ 922 \mathrm{~m}$ in 1991 and 1992 respectively Still, government continued to enact policy that would strengthen the operation of the Council. It enacted the Companies and Allied Matters Decree No. 1 of 1990, which articulated much of Nigeria's industrial development strategies and incentives for the next then (10) years and expanded the list of industrial establishments that foreigners could solely own. Only one list of Scheduled Enterprises was exclusively reserved for 100 per cent Nigerian equity ownership. All other businesses not contained in the list of Scheduled Enterprises were opened for up to either 100 per cent Nigerian or foreign participation except in the area of banking, insurance, petroleum prospecting and mining. It also made provisions for equity negotiation in the 'Unscheduled' enterprises. In effect, there were special considerations to foreigners because they were free to participate even in the 'Scheduled' enterprises. However, their participation must ensure that:

(a) a paid-up equity capital of not less than twenty million naira and, 
(b) a prior approval is obtained from the Industrial Development Coordination Committee.

With the view to further encourage foreign investors, government promulgated the Nigerian Enterprises Promotion Act in 1990. The incentives provided to industries in the Act fell within the following categories:

(a) Fiscal measures on taxation,

(b) Effective protection of local industries with import tariff,

(c) Export promotion of Nigerian-made products and,

(d) Foreign currency facility for international trade.

The purpose of these considerations was to encourage large scale production and operations by foreign investors in industries so as to meet local demands for export. Other strategies for attracting foreign capital included inter-alia the liberalisation of the foreign exchange regime and ease capital and dividend repatriation by foreigners. The act eliminated nearly all restrictions on foreign investment and ownership share reserve for indigenous investors.

\section{The Scourge Advance Fee Frauds}

The methodology of the commercial fraudsters was that they generally offered to share a percentage of a very large sum of money with the recipient. Mr. A. Giade, DCP, Special Fraud Unit, noted that commercial frauds were carried out in three stages. In the first stage, frauds were limited to:

Local activities involving cheating and obtaining money/goods under false pretences. Victims were usually indigenous businessmen and a few civil servants who were gullible enough to fall prey of the little tricks.

The second stage was:

When fraudsters further developed their schemes using cheques to induce delivery of goods and such cheques were returned unpaid on presentation.

At this stage, the Federal Government enacted the Dishonoured Cheques Offences Act of 1977. The third stage was more damaging to the Nigerian image. This was when fraudsters became more sophisticated and their operations extended beyond the local to the international scene. In 1991, government set up a Task Force known as Presidential Task Force on Trade Malpractices to combat financial crimes. The Force was placed under the Special Services Office of the Presidency, and its membership cut across broad spectrum of human endeavours. The responsibilities of the Task Force were to:

1. investigate all reported cases of 419 and other business malpractices;

2. determine the extent of financial and other losses by government and private individuals in respect of each case;

3 . $\quad$ ensure the prosecution of culpable cases; and

4. make recommendations to government.

In 1993, government again set up a sub-unit of the Task Force, known as the Special Fraud Unit. It consisted of specially trained detectives and its aim was to reduce the increasing incidents of fraud in Nigeria. Unfortunately, the hurdles in tracking down fraudsters through prosecutions were due to the inability of the duped foreigners to produce witnesses. The Inspector-General of Police, Ibrahim Coomassie noted that on several occasions, the Police sponsored trips of witnesses from Europe, Canada and Germany in search of evidence before the court but to no avail.

In the opinion of the United States officials, organised crime groups based in Nigeria directly targeted foreigners. The United States residents alone lost millions of dollars every year to financial fraud originating from Nigeria, and from Nigerian crime groups operating outside Nigeria. Mr. Mark Richard, United States Deputy Assistant Attorney-General described the internationalisation structure of the crime before the United States Congress in September 1996:

The ruse is that the potential victims are told that this pot of gold was, itself obtained through a fraud against the Nigerian Government... After providing the funds, the victim may be contacted by what appeared to be another organised group; frequently located in the U. S. A. which claims to be a "clearing house" for the $\mathrm{CBN}$-the representatives of which request the victim to provide additional funds to complete the transfer. 
Lieutenant Cornel J. M. Hassan, the Chairman, Presidential Task Force on Financial Crimes drew the attention of the Chamber to the modus-operandi of fraudsters:

It is pertinent to note that the perpetrators of this crime scan through International Journals, Magazines and Yellow pages to obtain names and addresses of foreign businessmen and companies. They write letters of bogus business proposals on forged government official stationery in thousands to unsuspected businessmen and firms, proposing fictitious or nonexisting businesses to their would-be victims. They request for their foreign bank account numbers for the transfer of nonexistent rewards of about $30-40 \%$ of the total sum to be given to them at the end of the deal.

The Chairman went further to recapitulate a typical advance fee fraud/scam:

A typical one started with a letter of solicitation, followed by telefax or telex messages. The letter often offer to transfer huge amounts of money, usually in US dollars, purported to be part proceeds of certain contracts, to the addressee's bank account, to shred in some proportion between the writer and the addressee. A favourable response to the letter is followed by excuses why the funds cannot be remitted readily and subsequently demands for proportionate share of payment of various "taxes" to facilitate the processing and remittance of the funds. The use of fake Governments, notable that of Central Bank of Nigeria (CBN), Nigeria National Petroleum Corporation (NNPC), and Federal Ministry of Finance (FMF) etc is a common practice.

Dr. Paul A. Ogwuna, highlighted CBN's views and recommendations on the issue. He explained that the Bank could not check the surge single-handedly, but that had to work in concert with both local and foreign government law enforcement agencies. In 1997, an International Financial Transactions Surveillance Office (IFTSO) was established in the Foreign Operations Department of the Bank to target advance fee fraud at the global level through routine verification of enquiries relating to scam letters, telefax, et cetera.

The allegations of unfavourable business environment could not be disputed. The President of the Chamber had in 1992 pointed out the implication of this and other constraints on bilateral trade and investment between Nigeria and the United States:

The international community is watching our economy and trying to decide whether ours is the most viable place to invest within the array of choices that they have. This is why the provision of a conducive investment climate by the government is most important. This is the foundation on which every bilateral Chamber can build on to attract foreign investors into the country.

In 1995, government promulgated Decree No. 13 of 1995 and the Miscellaneous Offence Tribunal. The objective was to track down fraudsters and prosecute them. Between 1995 and February, 1998, it was reported that four (4) million suspected scam letters were intercepted by the Nigerian Postal Services and about fifteen (15) million letters were sent back to Nigeria from about twelve (12) countries for being post-marked by the forged franking machines. The Task Force also investigated over eight thousand five hundred and sixty $(8,560)$ complaints and sixty-five (65) were charged before the various Tribunals. The Central Bank of Nigeria (CBN) noted that it spent between $\$ 4$ to $\$ 5$ million in both materials and financial resources to fight the scourge. CBN placed advisory advertisements in over eighty (80) newspapers and magazines in twelve (12) international languages in thirty-six (36) countries in an effort to forewarn all corporations and individuals who were likely to fall prey to the scam.

\section{Government and the Business Community Initiatives}

Immediately Industrial policy was launched, the Nigerian-American Chamber of Commerce in its usual reaction organised a seminar/workshop on "Companies and Allied Matter Decree". The purpose was to sensitise members of the private sector on joint ventures between Nigerian and American investors. At the end of the seminar, the Chamber recommended further amendments to the Nigerian Enterprises Promotion Decree of 1989 
and suggested a substantial deregulation of the regulatory and implementation requirements that were introduced under IDCC. It also criticised the maximum of sixty days requirement for the approval of all documents within IDCC purview. The Chamber suggested that government should provide:

A single comprehensive legislation encompassing every aspect of foreign investment in Nigerian joint ventures is introduced as a matter of urgency. Such legislation should be distributed widely through the Nigerian Embassies all over the world so as to bring the message of our improved investment climate to the would-be foreign investors.

$\mathrm{T}$ he Chamber noted the inadequate representation of the private sector on a Council that was charged with the great responsibility gamine to f making decisions that affected the business community. It therefore requested government to assure the private sector of its sincerity and commitment to industrial development through private sector initiatives. In its usual manner, the Chamber engaged the Information Minister, Prince Tony Momoh at its Luncheon organised in April 1990 to speak on "Nigeria-America Relations: What is the Future?" The Chamber's concern was due to the unsatisfactory response of American investors to the new industrial policy. Thereafter, it continued its pressure on government. In January 1991, the Chamber sent a deputation to President Ibrahim Babangida, asking for government's sincerity on the industrial policy; given the history of government's inconsistency of policy implementation. Indeed, government reassured the Chamber of its efforts to improve investment environment for investors, but felt that the response of American investors to Nigerian investment environment was not so much about policy formulation and implementation, but rather about the fraud scourge that had permeated the Nigerian business environment. Government believed that concerted efforts between it and the Chamber were needed to sensitise the American investors and inspire confidence and their interest in the economy.

A policy mission to the United States was organised by the government in 1990, while the Chamber organised a fact-finding tour of the United States markets; named "Exploratory Mission". At the Board Meeting of the Chamber in July 1991, its National President, Prince Julius Adelusi-Adeluyi reminded members of the Chamber's plans to visit the United States on a fact-finding tour and requested the Embassy to assist it in this regard. Mr. Terry Sorgi, the Commercial Attaché who was also at the meeting confirmed that a letter to that effect had already been sent to him and that he had discussed the matter with the Executive Director. He also disclosed that he was already in touch with certain trade agencies and Chambers of Commerce in New York, Philadelphia and Washington DC in connection with both the Federal Government's proposed trips as well as the Chamber's fact finding mission and was hopeful that positive responses would come shortly. The Commercial Attaché in the American Embassy had identified the Nigeria's image in international trade as the primary factor militating against foreign investors in the economy. The officials from the American Embassy at the meeting agreed that the Chamber should be in the fore-front of re-building the Nigerian image and seize the opportunity of the Presidential visit to the United States to redeem it at home and abroad.The Chamber then constituted a United States Mission Committee under the Chairmanship of Dr. U. J. Itsueli. Others on the Committee included; Mr. Moses Ihonde, Mrs. Elsie Ajose-Adeogun, Mr. Richard Huff, Mr. Terry Sorgi and the Executive Director of the Chamber, Mr. Richard O. Ikiebe. The tasks of the Committee were to: present creative ways to address the issues of dwindled American investments. identify short and medium term measures to restore American investment. plan the September exploratory mission prior to President Babangida's visit; and identify how to involve the Chamber in the planning the Presidential visit from the beginning.

The Presidential visit to the United States was eventually fixed for October 4, 1991. The United States Mission Committee of the Chamber ensured that the Chamber was involved in the planning of the mission. The mission became the Nigerian-American Investment Forum with the active participation of the NigerianAmerican Chamber of Commerce. The Business Forum was organised at Waldorf Astoria Hotel in New York and was tagged "The Nigerian-American Business Forum". The Nigerian participants at the Forum included eleven (11) top government officials and thirty-two (32) representatives from the Nigerian private sector.Three private sector's organisations were represented. These were the Manufacturing Association of Nigeria (MAN), represented by its President, Alhaji H. Adamu and five other members, the Nigerian-American Chamber of Commerce was represented by Prince Julius Adelusi-Adeluyi, its National President and twenty-one (21) other members of the Chamber. The National Association of Chambers of Commerce, Industries, Mines and Agriculture (NACCIMA) had three representatives. The ministries and parastatals present were the Raw Materials Research \& Development Council, Nigerian Export Promotion Council and the Central Bank of Nigeria, the Federal Ministry of Communication and the Nigeria Stock Exchange. Representatives from the 
United States included the Mayor of New York City, David Dinkins; Chief Executives of Mobil and Chevron Oil firms, Citi Bank and other American entrepreneurs with business interest in Nigeria. In all, there were four hundred and fifty (450) participants with three hundred (300) of them from the U.S. business community and the Nigerian businessmen resident in the United States. The objectives of the Forum were to:

(i) provide adequate information through the establishment of business centres in various parts of the United States, and provide regular dissemination of business information to the business community.

(ii) stimulate small and medium scale investment from United States through active participation of the black business community that have limited access to huge business capital and financial resources;

(iii) facilitate industrial development plan of the government.

(iv) organise similar fora in other parts of the US in Atlanta/Houston in the South, Chicago/Minnesota in the Midwest as well as other geographical areas for effective marketing of the Nigerian economy, and its potentials for foreign investment;

(v) explore possible avenues to encourage Nigerian entrepreneurs in the United States.

(vi) encourage the American firms operating in Nigeria to re-invest part of their resources; and

(vii) promote the Nigerian culture and ethics.

Panel discussions focused primarily on Nigerian-American trade relations. Panelists were drawn from the public and private sectors. Prince Julius Adelusi-Adeluyi, the President of the Nigerian-American Chamber of Commerce was part of the Panel of discussants. Other panelists were Ebitimi Banigo of Allstates Trust Bank, Mallam S. D. Umar of Continental Merchant Bank, Dr. U. J. Itsueli, Dubri Oil Company, Dr. (Mrs.) Ndi Okereke-Onyuike of the Nigeria Stock Exchange and Dr. (Mrs.) O. Aribisala of the Raw Material Research and Development Council (RMRDC). The composition of the Panel reflected the various segments of the Nigerian economy in trade and investment the organised private sector, the banking sector and the Nigerian capital market. Prominent issues raised during the Panel discussion were:

(i) Bureaucratic controls;

(ii) Incessant frauds perpetrated against potential foreign investors; and

(iii) African-Americans investment in the area of small and medium scale industries.

The reaction of the American press during the Nigerian-American Business Forum organised as part of the Federal government's policy mission in 1991 revealed the dispositions of the American public and private sectors to the menace. Throughout the duration of the mission, the United States Press consistently inundated readers with stories of the magnitude of frauds perpetrated by some Nigerian businessmen against foreign investors and "warned American investors to steer clear of the Nigerian economy". These stories were buttressed by circumstantial evidence provided by some American panelists on administrative incompetence of some government officials.

A participant narrated the ordeal of a businessman from Dallas, Texas who encountered these fraudsters through his effort to purchase an automated gas-oil worth US\$ 4.4 million in the 1980s through an opening of letter of credit. According to the participant, the business transaction later "proved to be a total failure because of the administrative incompetence of some government officials he met in Nigeria. Eventually, he neither obtained the product nor a refund of the huge capital invested".

Not minding the presence of the Nigerian President, the American Press reeled out different shades of crimes perpetuated by Nigerians. Definitely with these reactions, it was evident that there had been a build-up of antipathy in United States against the Nigerian business environment. This message was clear to the visiting Nigerian government and the private sector that were present, that the menace was a compelling factor determining the interests of foreign investments in the economy. The International Herald Tribune in the United States of September 24, 1991 carried the caption, "From Nigeria, a Business Proposition You Ought to Refuse", which involved a deal worth $\$ 17$ million. The National Broadcasting Corporation (NBC), a major Television Network in the United States feature uncomplimentary report on the Nigeria drug connection. The Washington Post of September 26, 1991 featured an article written by Jack Anderson and Dale Van Atta with the headline: "Nigerians Trying to Fleece U. S. Firms" the excerpt reads thus:

In 30 years of woffling (sic) between democracy and military dictatorship, some Nigerians have learned the lessons of capitalism too well long regarded by law enforcement agencies as among the best in the business when it comes to cards scams, Nigerian crooks are branching out. The latest con involves separating American businesses from their money in save that are notable for their brashness and ingenuity. 
The attention of the Nigerian-American Chamber of Commerce immediately shifted to solution to the image problem. Its National Secretariat organised the first International Seminar on Advance Fee Fraud and other Financial Crimes at another Business Luncheon Meetings in 1997. The objectives of the seminar were to:

1. afford the world an insight into the Nigerian perspective on the issue of fraud,

2. give Nigeria the opportunity to let the world know her own side of the issue and,

3. expose the damaging impact of "419" on the Nigerian image within the international community.

Since the Police was directly concerned with criminality, the Guest Speaker at one of luncheon meeting was the Inspector General of Police, Ibrahim Coomassie. He examined "The Nigerian Police and the Emergent Scenario of International Crime Prevention, Detection and Control." In another business luncheon, he was invited as a guest speaker to sensitise the business community on "Security Incentives for Business Activities in Nigeria". Relevant government's departments were drawn into the discourse. Ibrahim Coomassie analysed the different security problems including frauds which permeated international business environment. Frauds included, breach of copy right, unwarranted proliferation of wonder banks, goods piracy on high seas, ports rats problems, insurance frauds, maritime offences, et cetera. Ambassador Adamu Mohammed, the Special Adviser to the Head of State on Drugs and Financial Crimes, drew the attention of the Chamber and the international community to "The Nature, Types and Manifestations of Financial Crimes in Nigeria". Mr. William Twadell, U. S. Ambassador to Nigeria exposed the "Concept and Mode of Advance Fee Fraud". Dr. Paul Ogwuma, the Central Bank Governor, highlighted the efforts of CBN in the fight against the scourge. Paul Ogwuma noted that Bank established liaison with the American Secret Service, Metropolitan Police (Company Fraud Department) London, Hong Kong Police and Serious Fraud Office and the New Zealand Police. This collaboration produced a prosecutorial guidelines and co-ordination of countermeasures on international Advance Fee Fraud activity.

In June 1996, the collaborative endeavour between the United States of America Secret Service, the Nigerian Police Federal Investigation \& Intelligence Bureau and CBN Security Services Department resulted in sixteen search warrants being executed and that forty-three Nigerians were arrested in Lagos for Advance Fee Fraud. The Chamber volunteered to work with the Police to find a scientific solution to the problem of scam letters of 419 that had so badly dented Nigeria's image abroad. It immediately entered into dialogue with the Nigerian Police Force and arranged a joint seminar with the Police to deal with the problem. The Chamber also requested for experts on fraud from the international community. Following the request, the United Kingdom and German governments sponsored specialist criminologists from their respective countries to attend the Lagos seminar. At the same time, the U. S. embassy appointed two America Secret Service agents who were expert criminologists to work with the Nigerian Police.

One important finding during the workshop was that, contrary to the hue and cry from the foreign media and expatriates, both Nigerians and foreign investors were liable. According to the Central Bank Governor:

It is true that Nigerians engaged in such criminality, but bogus proposal should at least prompt any genuine and honest foreign businessmen or corporation to enquire, but because of their greed and gullibility, they too did not.

The attention of the business community was also drawn to the dubious act of some foreign investors who as a result of their own greed; were duped by the antics of the fraudsters:

Only a criminal would believe that he can obtain millions of dollars from a foreign country for just offering his bank account number in which to deposit illicit money; especially when the proposal came from a person he has never met, and with whom he had no previous subsisting relationship. Indeed this is the highest stage of greed and dishonesty.

In 1996, several cases of " 419 " were perpetrated and there were cases that elucidate the fact that the so called 'foreign victims' were most of the time, persons of dubious character who had the same criminal tendencies as the initiating fraudsters. For example, on August 8, 1996, Konke Wienkamp, a German was invited by some fraudsters to consummate a deal to lift three million barrels of crude oil based on a fake contract with the Nigerian National Petroleum Corporation (NNPC). Although, the German agreed to assist the Special Fraud Unit to track down the Nigerian fraudster, but shortly after this arrangement, he absconded from the hotel. Under a similar circumstance, a Member of Parliament of the Peoples Republic of Bangladesh, Mr. Mushud Resa was in Nigeria in August 1996. He was lured into an illegal and fake oil deal in respect of which a cheque 
of $\$ 47.3$ million was to be issued by CBN into his account. He was however immediately turned back by the officials at the Airport. These two incidents show that without favourable responses from foreigners, Nigerian fraudsters would automatically be out of business.

At the international and domestic levels, the eradication of " 419 " and corruptions were linked to the survival of companies and indeed the national economy. At this point, the Chamber began to focus on sound commercial ethics, based on the premise of corporate governance and enterprise culture. The international nature of the crime informed the organisation of a Commonwealth Business Forum in 1997. The forum represented the private sector and state-owned corporate sector in Britain. At the end of the forum, a communiqué was passed which stipulated that:

Every Commonwealth country (should) create or reinforce institutions to promote best practice. In corporate governance in particular, codes of good practice establishing standards of behaviour in the public and private sector should agree to secure greater transparency and to reduce corruption.

In order to counter the Advance Fee Fraud and other related Offences, government promulgated Decree No. 13 of 1995 and the Miscellaneous Offence Tribunal. Government further created the Office of the Special Adviser to the Head of State and Commander-in-Chief on Drugs and Financial Crimes to serve as Secretariat for the Task Force and its name changed to the Presidential Task Force on Financial Crimes. Its objectives were to:

(a) advise the Head of State on policy initiatives,

(b) relate with other nations and international bodies,

(c) co-ordinate the activities of all the agencies involved in the war on Drug and Financial Crimes,

(d) formulate the National Narcotics, Money Laundering and Advance Fee Fraud Control Policy with succinct structures for its implementation and,

(e) promulgate Money Laundering and Advance Fee Fraud Decrees Nos. 3 and 13 of 1995 respectively.

Despite the efforts made, economic depression and commercial fraud continued to destroy Nigeria's domestic and external business environments to the extent that the economy was no longer attractive to foreigners. Internally, the activities of manufacturers also declined. The Manufacturers Association of Nigeria (MAN) in its 1996 report on the state of the manufacturing sector noted that industrial capacity utilisation in Nigeria dropped from 36 per cent in the first half of 1993 to below 32 per cent in the first six (6) months of 1994. By the first six months of 1996, it declined further to 27 per cent. This was because the ability of the firms to purchase foreign exchange for industrial inputs either in form of raw materials or machineries was seriously impaired. The index of industrial production reflected a decline in output in the first half of 1993, while the consumer index in the first half of 1994 registered 41.5 per cent increase over the same period in 1993. The problems were compounded by:

(i) poor and inefficient infrastructural services,

(2) ill-conceived policies and poor policy implementation,

(3) bureaucratic inertia,

(4) high cost of funds resulting from high interest rates and massive depreciation of the naira,

(5) spiral inflationary trend arising from persistent high cost of production and,

(6) exorbitant interest rate and the various taxes and levies at Federal, States and Local Government levels.

Besides the issues of fraudsters and inefficient infrastructure, the growing rate of human right abuses and drug trafficking worsened Nigeria's image in the comity of nations. Nigeria was declared a major drugtrafficking nation and one of the most corrupt nations in the international system. The United States particularly singled out Nigeria as a "worldwide hub of narcotics trafficking and money laundering activities." And even that "organised crime groups based in Nigeria... and Nigerian crime groups operating outside Nigeria cost U.S. residents hundreds of millions of dollars every year." Twaddell, the American Ambassador identified the implication of the various shades of Nigerian crimes on the American as at 2000:

Nigerian criminal and narcotics syndicates victimize thousands of $U$.

S. citizens. Advanced Fee Fraud and other financial crimes cost Americans hundreds of millions of dollars annually. Nigerian drug traffickers accounted for 50 per cent of the heroin trafficked world wide and ...responsible for a growing percentage of the global movement of cocaine. Inevitably, as a consequence, Nigeria has become a significant hub for money laundering and other spin-off criminal activities. 
According to the Nigerian-American Chamber of Commerce, the contraction in aggregate industrial output reflected on developments in all major components of the industrial sector: mining, manufacturing and electricity consumption, which recorded output declines of 5 per cent, 2 per cent, 3 per cent, 9 per cent and 3.6 per cent respectively. Nigeria's balance of payments weakened from a surplus of N1, 077.7 million ( $\$ 15.0$ million) in 1997 to a deficit of N220.667 million (\$2,873.0 million) in 1998. The current account balance deteriorated from surplus of $\mathrm{N} 240,180.3$ million (\$3,438.7 million) to 8.5 per cent of GDP in 1996 to a deficit of N330,190.0 million (USD 4,297.8 million) in 1997, which represented 3.5 per cent of GDP in 1998. Consequent upon these developments and more importantly because of the long period of transitional programme to civilian rule in Nigeria, the United States government in 1996 clammed down on Nigeria. This was the second time in the Nigerian-American relations that the Nigerian-American Chamber of Commerce played the role of a mediator between both countries. The first was in Nigerian civil war when diplomatic relations broke down between both countries during the war.

The Chamber quickly sought audience with the American Ambassador to Nigeria to mediate in the face-off between the two governments. The Chamber requested for a meeting with the Special Departments of the United States Government, but what was eventually arranged was an inter-agency (Ministerial) meeting coordinated by the Department of State, which took place on May 16, 1997. The Nigerian trade delegation was led by the Departments of States Commerce and Transportation, the Federal Civil Aviation Authority and the Small Business Administration. At the time the Chamber requested for the meeting, its intentions were to ensure that United States' embargoes on Nigeria were reviewed considerably. Dundas C. McCullough, the Country Officer for Nigeria at the Department of States and leader of the American delegation, noted that, American government's worries were on Nigeria's democratisation process, anti-drug campaign, human right abuse, financial crimes and commercial mal-practices. While claiming not to speak for the government, the Chamber subtly appealed to the American government to understand the peculiarities of Nigeria's adoption of foreign political development processes, which had no strong correlation with her traditional settings. The association however, appealed for restraint over America's desire for Nigeria's return to civil rule and averred that what Nigeria needed most from the American government was support and that in any case:

It is not right for any one to give us pass mark only when we are perceived to be doing their will. Nigerians could never be Americans or British for that matter and so it is wrong to judge us on the basis of American, British or any other foreign standard (and that)...the matter of the law, maintenance of the rule of law should be seen as the aspiration.

On the concern of the American government for human rights in Nigeria, the Chamber noted that in all the cases specified, "due process had been observed and when proper legal determination had been made our call should be for amnesty, not human rights". The association also debunked the idea of Nigeria's involvement in drug, the problems of fraudsters and internal insecurity. It warned that the United States propaganda against Nigeria was detrimental to her economic growth as it gave rise to "a build-up of antipathy against Nigeria.

As a follow-up to its internal campaign against frauds, the National President of the Chamber, Moses O. Ihonde led a Trade Mission to four commercial cities in the United States, namely, New York, Washington D. C., Atlanta and Houston between 9th and 25th of May, 1997. The objective of the mission was to broker peace between both governments. This was also a follow-up of the initiative the Board of the Chamber took in September, 1996 when it sought audience with the American Ambassador to Nigeria as a result of the face-off between the two governments. The mission achieved little as American government and investors developed stronger aversion to military rule in Nigeria. This aversion was expressed in 2000 when Ambassador Twaddell in retrospect cast people's minds to the core problem in Nigerian-American bilateral economic relations:

The emergence of a democratic Nigeria in May 1999 ended years

of corrupt military rule and strained relations with the United

States.

The war against international crime also became an international concern. The international community became harder on international crimes. In December 2000, a new United Nations Convention against Transnational Organised Crime was signed in Palermo, which enforced compliance of all nations in the fight against organised crime.

Between 1997 and 2006, State Chapters of the Chamber had equally become vocal. At the national and state levels, the Chamber viewed the issue of international crime from different perspectives. At home, the struggle by the Chamber for conducive foreign investment was further advanced by its State Chapters. In 1998, the Kaduna Chapter of the Chamber organised a two-day seminar on Advance Fee Fraud and Other Financial 
Crimes: Searching for a Solution to the Problem. In attendance was Ambassador Mr. Twaddell of the U. S. as well as members of the Provisional Ruling Council, the Military Administrator of Kaduna State and members of the Diplomatic Corps. The calibre of government functionaries from both countries in attendance showed the determination of the Chapter to tackle trade and investment problems. At the end of the seminar, the Chamber concluded that a democratic rule was indispensable to the conducive of diplomatic relations between the two nations and recommended to the government that:

A more democratic Nigeria will enable the U. S. to cement diplomatic ties and allow Nigeria to assume its natural role on issues of mutual interests in international fora. To this end, Nigeria must instill transparency in its political processes and decision-making and engender accountability in all aspects of government. The condition for a free and transparent electoral system must be created and international confidence in the legitimacy of Nigeria's leadership and new direction.

While these fight against commercial frauds remained at the front burner in official and the private sector's circles, a study by the United Nations Conference on Trade and Development (UNCTD), estimated total net foreign Direct Investment (FDI) in Nigeria to be \$1.539 billion for 1998. Meanwhile, in 1997, the Chamber introduced a new dimension to its trade promotion strategies. Its American Businessman's Day metamorphosed to a Trade Fair in December 1997, although the Chamber had been participating in the International Trade Fair organised by the Lagos Chamber of Commerce since 1962.

The fight against commercial crimes and corruption was also waged at corporate level. The aim was develop high ethical standards in their operations and from their employees as one way of addressing the image problem. In 2001, the Chamber examined the issue of "Corporate Governance and Enterprise Culture" in a democratic political structure with the aim of raising the standard of business ethics at companies' level to meet the global business ethics requirements.It re-examined the complex internal dynamics in the business environments and throughout the 1990s, it concentrated on organising seminars/workshops on issues bordering on investment opportunities in the Nigerian economy. Among such was "Managing Small Scale Industries and Export Marketing: Problems and Prospects and Marketing of Goods and Services: The Way Forward". The Government Liaison Committee of the Chamber made effective contact with many functionaries at various levels whose positions were relevant to its aims and objectives.

\section{Conclusion}

This paper has examined the scourge of financial frauds and the initiatives of the government and business community. Although their prevalence cannot be totally responsible for low turnout of foreign investors, they were indeed singled out as a fundamental factor.

\section{References}

[1]. For detail discussion of trade mal-practices on the West coast in this period, see Walter O. Ofonagoro, Trade and Imperialism in Southern Nigeria: 188-1929. New York: Nok Publishers International, 1979.

[2]. Remarks by H. E. Walter C. Carrington, Ambassador of the United States before the Nigerian-American Chamber of Commerce on the occasion of the American Businessman's Day, Eko Hotels Ltd., October 30, 1996. Official Text United States Information Service.

[3]. Olajide Aluko, "Oil at Concessionary prices for Africa: A Case Study in Nigerian Decision-Making", in G. O. Olusanya and R. A. Akindele, (eds.) The Structure and Processes of Foreign Policy Making and Implementation in Nigeria, 1960-199, p. 328.

[4]. Yusuf Bangura, "Crisis in Sierra Leone and Nigeria: A Comparative Study", Journal of African Marxists Issues 9, June, p. 34.

[5]. National Economic Council, Expert Committee Report on 'The State of the Economy'. 1983.

[6]. Yusuf Bangura, "IMF/World Bank Conditionality and Nigeria's Structural Adjustment Programme, Kjell J. Havnevik (ed.) The IMF and the World Bank in Africa:Conditionality, Impact and Alternatives. Scandinavian Institute of African Studies, Uppsala, 1987 , p. 96.

[7]. Enver Carim and Catherine Fear (eds.) Africa Guide, 1983. England: World of Information, p. 271.

[8]. 1984 Budget: An Address to the Nation by Major-General Muhammadu Buhari, on $7^{\text {th }}$ May, 1984, p. 4.

[9]. Central Bank of Nigeria: Economic and Financial Review, Vol. 19, No. 2, December, 1981, p. 3.

[10]. Ibid.

[11]. Enver Carim and Catherine Fear (eds.) Africa Guide, 1983. England: World of Information, p. 273.

[12]. Ibid.

[13]. A National Committee on Industrial Development (NCID) was established in August, 1989. NCID became a platform for collaboration between the public sector, the private sector operators, researchers, academics and financial experts with the objective of articulating the path to the nation's industrial development process. The Industrial Development Coordination Act established the Industrial Development Co-ordinating Council (IDCC); launched in Abuja, which composed of six Federal Ministries: Industries and Technology; Chairman, Finance and Economic Development, Trade and Tourism, Internal Affairs, Agriculture and Employment Labour and Productivity. The Council served as a one-step approval centre for new ventures. Its function was to reduce the bottlenecks inherent in application processing, issuance of initial expatriate quotas, and giving final approval to investors. 
[14]. Hassan A. Saliu," Nigeria-West Relations Under Economic Diplomacy: Dependency or Mutual Gains" in Nigerian Forum, NIIA, May-June, 1996. p. 98

[15]. Olusegun Akinsanya, "Economic Diplomacy and Nigeria’s Foreign Policy", Op Cit. .

[16]. Ibid

[17]. Ibid.

[18]. Ibid

[19]. A Lecture delivered by Mr. A. Giade, DCP, Special Fraud Unit at a 2 Day Seminar on "Advance Fee Fraud and Financial Crimes" organised by the Nigerian-American Chamber of Commerce, kaduna Chapter, 18-19 August, 1998.

[20]. Ibid.

[21]. A Lecture delivered by Mr. A. Giade, DCP, Special Fraud Unit at a 2 Day Seminar on Advance Fee Fraud and Financial Crimes organised by the Nigerian-American Chamber of Commerce, Kaduna Chapter, 18-19 August, 1998.

[22]. CROSSROADS, The Public Affairs Section, U. S. Embassy, Lagos, Nigeria, Vol. 7, No. 3, 1997, p. 2

[23]. Ibid.

[24]. A Speech delivered by Mr. Moses Ihonde, National President of the Nigerian-American Chamber of Commerce at the Seminar on Financial Crimes, Arewa House, Kaduna, on 18th August, 1998.

[25]. Ibid.

[26]. "Nigeria-American", The Journal of the Nigerian-American Chamber of Commerce, No. 2, January-June, 1992 , p. 37.

[27]. A Lecture delivered by Mr. A. Giade, DCP, Special Fraud Unit at a 2 Day Seminar on Advance Fee Fraud and Financial Crimes organised by the Nigerian-American Chamber of Commerce, Kaduna Chapter, 18-19 August, 1998.

[28]. Lieutenant Cornel J. M. Hassan, the Chairman Presidential Task Force on Financial Crimes, "Efforts of Presidential Task Force in Combating Financial Crimes" A Paper delivered at the International Seminar/Workshop Organised by Nigerian-American Chamber of Commerce, Arewa House, Kaduna on 18th and 19th August, 1998.

[29]. "Nigerian-American", Journal of the Nigerian-American Chamber of Commerce, Jan-Jun. 1992, pp. 27-8.

[30]. Ibid.

[31]. NACC, Minutes of the Board Meeting held on Tuesday July, $9^{\text {th }}, 1991$ at the Chamber's Secretariat.

[32]. Ibid.

[33]. Ibid

[34]. Ibid.

[35]. A Report of the Nigerian-American Chamber of Commerce Business Forum, New York, United States of America, October 4, 1991, January 29, 1992.

[36]. Ibid.

[37]. Ibid.

[38]. Ibid.

[39]. Ibid

[40]. A Report of the Nigerian-American Chamber of Commerce Business Forum, New York, United States of America, October 4, 1991, January 29, 1992.

[41]. Ibid

[42]. Ibid.

[43]. International Herald Tribune, September 24, 1991.

[44]. A Paper delivered by Lieutenant Cornel J. M. Hassan, the Chairman Presidential Task Force on Financial Crimes, "Efforts of Presidential Task Force in Combating Financial Crimes" International Seminar/Workshop Organised by NigerianAmerican Chamber of Commerce, Arewa House, Kaduna on 18th and 19th August, 1998.

[45]. Ibid.

[46]. A Paper delivered by Lieutenant Cornel J. M. Hassan, the Chairman Presidential Task Force on Financial Crimes, "Efforts of Presidential Task Force in Combating Financial Crimes" International Seminar/Workshop Organised by NigerianAmerican Chamber of Commerce, Arewa House, Kaduna on 18th and 19th August, 1998.

[47]. Ibid.

[48]. Ibid.

[49]. A Paper delivered by he Honorable of Industries, Air Vice Marshall M. Yahaya Keynote Address at the Business Forum in New York, United States of America, October 4, 1991.

[50]. "Nigerian American" The Journal of the Nigerian-American Chamber of Commerce, No. 007, 1995 , p. 12.

[51]. Ibid.

[52]. CROSSROADS, The Public Affairs Section, U. S. Embassy, Lagos, Nigeria, Vol. 7, No. 3, March 2001.

[53]. A text of the Ambassador Twaddell's remarks On "U. S. Ambassador Twaddell Surveys U.S.-Nigerian Relations, in Crossroads, The Public Affairs Section, U. S. Embassy, Lagos Nigeria, p. 14.

[54]. "Nigerian Economy: Problems and Prospects," in "Nigerian-American" Journal of the Nigerian-American Chamber of Commerce, Jan.-June, 2000, p. 31.

[55]. Ibid.

[56]. "Nigerian-American" The Journal of the Nigerian-American Chamber of Commerce, July-Dec. 1997. pp. 15-16.

[57]. Ibid.

[58]. Ibid.

[59]. CROSSROADS, The Public Affairs Section, U. S. Embassy, Lagos, Nigeria, Vol. 6, No. 5, May 2000 , p. 14.

[60]. Ibid. p. 13 .

[61]. "Nigeria-American", The Journal of the Nigerian-American Chamber of Commerce, No. 009, 1998.

[62]. United Nations Conference on Trade and Development, Foreign Direct Investment in Africa: Performance and Potentials, June, 1999.

[63]. Annual Report and Account: NACC, 1999, 2000 and 2001. 